\title{
Teacher Interpersonal Communication With Autism Students In Inclusive School
}

\author{
Faiqotul Himmah ${ }^{1, *}$ Wiwik Widajati $^{1}$, Budiyanto Budiyanto ${ }^{1}$ \\ ${ }^{1}$ Department of Special Education, Universitas Negeri Surabaya, Indonesia \\ *Corresponding author. Email: faiqotul.20002@mhs.unesa.ac.id
}

\begin{abstract}
In teaching and learning activities, communication is the most important factor as the main source in conveying knowledge. The purpose of this study was to describe the interpersonal communication of autistic students with teachers. This research uses qualitative research methods with qualitative descriptive research. Data was obtained through observation and interviews. The data obtained were then analyzed using the member check technique. The results showed that interpersonal communication between teachers and students with autism was quite good. Some aspects that affect interpersonal communication between teachers and students with autism include openness, empathy, support, a sense of positivity, and equality
\end{abstract}

Keywords: Interpersonal communication, Autism student, Inclusive school.

\section{INTRODUCTION}

Communication is something that cannot be separated from human life, both verbal and nonverbal. Through communication, a person can express feelings, show self-identity, desires, hopes, build self-concept, work together, and can know and understand all events that occur in life around him. Even though communication, can influence people who are partners in communicating [1]. Communication can occur if all elements of communication can synergize properly. Age is one of the determinants of the effectiveness of communication and the background of communicators and communicators. The condition of communicators and communicators in the context of age can affect the context and message to be conveyed.

Autism is a developmental behavior disorder in children which is generally caused by abnormalities in the structure or function of the brain [2]. Autism occurs in the first 3 years of life which is characterized by limitations in social relationships, abnormal communication, and restricted, repetitive, and persistent behavior. Autism itself is not a disease but a syndrome or a collection of symptoms, where there are social deviations, language skills, and concern for the environment.
Communication disorders are one of the characteristics of students with autism such as difficulty starting conversations, responding to other people's communicative offers, and engaging in reciprocal conversations [3]. In addition, autistic students also have difficulty understanding and integrating non-verbal behaviors such as eye contact, body language, gestures, and facial expressions into their communication [4]. Therefore just small talk and social relationships can be a challenge for them. In addition, some students with autism are hypersensitive to environmental stimuli, such as bright light, loud noises, or strong smells. These factors make face-to-face interactions difficult, and for adolescents and adults with autism who want to make friends, can lead to feelings of loneliness and depression [5].

Teachers must be able to give messages to students well, so there must be good communication between teachers and students with autism. Teachers are also needed to continue to share ways of interacting and communicating so that the messages conveyed can be accepted and understood by autistic students. Furthermore, autistic students also need the help of schools and teachers to create self-confidence so that they can interact comfortably in the community. Until later, students can socialize with other normal people as individuals with limitations 
who can stand on their own without depending on their parents or other people around them [6].

One way that can be done to reduce the inability of autistic children in the social world is to train them to carry out interpersonal communication with others [7]. If communication is done well, there will be good social interaction between autistic children and their environment. Interaction between students at school affects the aspects of cooperation, competition, and conflict that exist in students [8], thus helping to improve students' skills in social relations.

Inclusive schools are an alternative for students with autism. With an inclusive school, teachers and regular students can recognize and understand the condition of students with autism, although in class not all regular students understand the condition of students with autism. In the learning process, students with autism need a companion teacher who can support their development, because the teacher is the most influential variable in shaping the learning process for students with autism. Teachers play a role in helping social interaction in children to create dynamic and harmonious communication in the school environment [9]. Because in inclusive schools, students with autism will be faced with a new environment that is different from the environment in special schools. From observations that have been made at SMP Negeri 40 Surabaya, it is known that students with autism have problems communicating with other people. This can be seen when learning in class, students with autism look busy with themselves and pay less attention to the teacher who is teaching. Students with autism do not seem to understand how to communicate with their environment, making it difficult for students to express their expressions and have difficulty following teacher instructions when called or asked to read. In addition, students with autism also only want to be close to certain children who have been known from previous schools and are still not comfortable with friends or teachers at their current school.

Based on the explanation above, the writer wants to know how the role of interpersonal communication between teachers of autistic students is. By knowing the role of good communication, effective communication between teachers and students with autism is very necessary because it makes the relationship between the two good. Interpersonal communication between teachers and autistic children can overcome the problems of autistic children. As it is known that good interpersonal communication can lead to positive behavior, while bad interpersonal communication can also lead to negative behavior. However, it is different from autistic children who cannot distinguish positive and negative behavior, so to avoid the formation of negative behavior, it is necessary to build adequate communication in the school environment for autistic children. Effective interpersonal communication includes openness, empathy, support, a sense of positivity, and equality [10]. It is hoped that interpersonal communication can help students with autism communicate better in inclusive schools and other social environments.

\section{METHODS}

\subsection{Research Design}

This study provides an approach to the research problem using a qualitative descriptive method. The qualitative descriptive method is a research method used to examine the condition of natural objects where the researcher is the instrument itself. Researchers used a qualitative descriptive approach so that researchers could blend in to find out more deeply the communication between autistic students and teachers in the classroom. Data collection techniques using observation and interviews.

\subsection{Research Subject}

Based on the previous description, the subjects in this study were class teachers who teach at SMP Negeri 40 Surabaya and 7th-grade autism students. Researchers consider the criteria for teachers as informants are teachers who teach in autism classrooms, namely 7 th-grade teachers.

\subsection{Data Analysis}

The data were analyzed by member check technique, which is the process of checking the data obtained by the researcher to the data provider. The purpose of a member check is to find out how interpersonal communication occurs in teachers and students with autism.

\section{RESULTS AND DISCUSSIONS}

\subsection{Openness}

There is a desire to express ideas or even similarities and open without shame. Both parties who communicate can understand each other and understand each other's personalities. Based on observations, when called by the teacher in class, autistic students can respond by answering verbally. Teachers also call autistic students several times to make sure they stay focused on learning in class. 
When outside the classroom, the teacher also greets autistic students, invites them to talk, and advises them. This is supported by the results of interviews with teachers. Openness is one of the important influences if you want to create effective communication between teachers and students with autism [11]. In openness, the teacher has taken much of an approach as possible to understand the characteristics of autistic students. Teachers also try to understand the communication conveyed by autistic students, because autistic students often convey their communication in non-verbal forms such as head nods or hand swings. This makes teachers have to repeatedly ask autistic students to make sure what students want to convey to their teachers.

\subsection{Empathy}

Empathy is one's ability to project oneself into the role of another. If communicators can empathize with one another, effective communication is possible. The empathy that the teacher gives to students makes students feel more valued. Based on interviews, during learning activities in the classroom the teacher tries to understand the conditions and needs of autistic students to convey learning materials well. The teacher also several times allowed students to ask questions if there was material that was not understood and did not impose their will if the autistic student did not want to follow the instructions given. This is supported by observations, where the empathy from the teacher to the autistic student can increase and establish emotional closeness between the two parties and deepen the understanding of the character of autistic children. Empathy teaches to be able to understand the motivations and experiences of others, feelings, and attitudes as well as hopes and desires of others for the future [5]. Empathy makes a person able to adjust his communication.

\subsection{Support}

Opinions, ideas, or ideas that are conveyed freely without feeling constrained and supported by other parties. Support can be given in the form of appreciation which is expected to spur one's motivation in achieving the desired goals. Based on interviews, the attitude of support shown by the teacher is to give appreciation in the form of verbal praise to autistic students if they succeed in answering questions and carrying out teacher instructions well. Appreciation is also given nonverbally by clapping. The existence of effective communication raises the convenience of interpersonal communication between teachers and students with autism. This can be seen from the observation, after being given appreciation by the teacher, students with autism can provide positive feedback and understand the instructions given directly by the teacher. In this case, the teacher uses simple strategies such as giving praise and positive affirmations [11].

\subsection{Possitivnes}

A person's ability to see himself positively and respect others. A positive attitude cannot be separated from efforts to acknowledge the existence and importance of others. Positive encouragement usually comes in the form of praise or appreciation and consists of the behaviors we normally expect. Based on interviews, when autistic students were seen in class that they were not in the mood or were not enthusiastic about participating in learning, the teacher respected students by not forcing autistic students to answer when given questions or instructions. The teacher also asked the autistic student, what made him not in the mood today. After that, the teacher offers autistic students to continue studying in the classroom or the resource room so that students can feel more comfortable. With this understanding from the teacher, autistic students slowly want to get closer to the teacher to communicate with him. This can be seen from the results of observations when several times students with autism sometimes behaved just to ask the teacher's attention while in class. The teacher responds to this and can provide an explanation that can be understood by students with autism. Communication based on patience, sincere intentions, and positive thinking creates effective communication for students with autism [6].

\subsection{Equality}

Interpersonal communication will be more effective if the atmosphere is equal. After all, nothing can be the same between two people communicating with each other. Interpersonal relationships characterized by equality, disagreement, and conflict are seen as an attempt to understand the inevitable differences [12]. Based on interviews, the learning given to autistic students has been adjusted to the student's cognitive abilities. Although there are some differences in treating autistic students in the classroom, of course with the conditions that have been considered previously, the teacher has the same affection for both autistic students and regular students in the class. This is supported by the results of observations, when learning takes place, the 
teacher does not exclude the presence of autistic students in the classroom.

An understanding of the characteristics or characteristics of autistic students must be understood correctly, that what is desired and wants to be conveyed by autistic students is following their thoughts [12]. That way, teachers can anticipate situations to avoid unwanted conflicts. Teachers also need to understand that autistic students have the same rights in learning needs as regular students.

\section{CONCLUSIONS}

Based on the results of qualitative research using observation and interview techniques carried out there are several aspects that influence the interpersonal relationship between teachers and students with special needs autism, among others:

Open communication between teachers and students with autism is developing well. It can be seen how teachers approach students with autism by also communicating outside the classroom to increase closeness with students with autism.

The attitude of empathy carried out by the teacher is good, it can be seen from how the teacher can understand the conditions and needs of students with autism in learning in the classroom. That way, emotional closeness can slowly be established between teachers and students with autism.

Teachers have provided support to students with autism in the form of verbal praise and non-verbal form of applause. Students with autism give positive feedback after giving praise and students can understand instructions well.

The positive attitude of the teacher has been carried out in the daily life of autistic students both inside and outside the classroom. Teachers can understand the condition of autistic students who are not in the mood in class so that it creates comfort for autistic students who are slowly able to open up to their class teachers.

The teacher can provide an equal atmosphere to all students in the class and tries not to distinguish between students with autism and regular students with certain considerations. By understanding the characteristics of students with autism, teachers can prevent students with autism from unwanted conflicts.

\section{AUTHORS' CONTRIBUTIONS}

All authors conceived and designed this study. All authors contributed to the process of revising the manuscript, and at the end all authors have approved the final version of this manuscript.

\section{REFERENCES}

[1] D. Mulyana, "Ilmu Komunikasi Suatu Pengantar”, Bandung: PT. Remaja Rosdakarya, 2000

[2] N. Daulay, "Struktur Otak dan Keberfungsiannya pada Anak dengan Gangguan Spektrum Autis: Kajian Neuropsikologi”, Buletin Psikologi, vol. 25, pp. 11-25, 2017

[3] I. M. Eigsti, A. B. de Marchena, J. M. Schuh, E. Kelley, "Language acquisition in autism spectrum disorders: a developmental review", Research in Autism Spectrum Disorders, vol. 5, pp. 681-691, 2011. DOI: https://doi.org/10.1016/j.rasd.2010.09.001

[4] S.M. Srinivasan, I. M. Eisgti, T. Gifford, A. Bhat, "The effects of embodied rhythm and robotic interventions on the spontaneous and responsive verbal communication skills of children with Autism Spectrum Disorder (ASD): A further outcome of a pilot randomized controlled trial", Research in Autism Spectrum Disorder, vol. 27, pp. 73-78, 2016.2 DOI: https://doi.org/10.1016/j.rasd.2016.04.001

[5] J. E. Lainhart, S. E. Folstein, "Affective disorders in people with autism: a review of published cases", Journal of Autism and Developmental Disorders, vol. 24, pp 587-601, 1994. DOI: https://doi.org/10.1007/BF02172140

[6] Y. G. Valentine, Sugandi, K. M. Boer, "Pola Komunikasi Interpesonal Guru Terhadap Anak Autis di SLB Ruhui Rahayu Samarinda", eJournal llmu Komunikasi, vol. 7, pp. 135-149, 2019. ISSN: 2502-5961

[7] S. A. Ritongga, E. J. Hasibuan, "Komnikasi Interpersonal Guru dan Siswa Dalam Mengembangkan Bakat dan Kreativitas Anak Autis di SLB Taman Pendidikan Islam (TPI) Medan", Jurnal Simbolika, vol. 2, pp. 189-199, 2016.

DOI: https://doi.org/10.31289/simbollika.v2i2.1030

[8] Z. Melchioriyusni, A. Said, "Interaksi Sosial Siswa dengan Kelompok Teman Sebaya di 
Sekolah dan Implikasinya terhadap Pelayanan BK", Jurnal Konseling dan Pendidikan, vol 1, 2013. DOI : https://doi.org/ 10.29210/11700

[9] W. Sartika, A. Said, I. Ibrahim, "MasalahMasalah Interaksi Sosial Siswa dengan Teman Sebaya di Sekolah", Jurnal Ilmiah Konseling, vol. 2, pp. 141-145, 2013. DOI: https://doi.org/10.24036/0201321877-0-00

[10] M. Muhammad, "Komunikasi dan Regulasi Penyiaran,” Jakarta: Erlangga, 2007

[11] C. N. G. Chao, W. S. E. Chow, C. Forlin, F. C. Ho, "Improving teachers' self-efficacy in applying teaching and learning strategies and classroom management to students with special education needs in Hong Kong", Teach. Educ., vol. 66, pp. 360-369, 2017. DOI: https://doi.org/10.1016/j.tate.2017.05.004

[12] K. Anwar, R. Saleh, M. Comn, "Komunikasi Interpersonal Mahasiswa Pada Media Sosial Facebook", Jurnal Ilmiah Mahasiswa, vol. 3, pp. 465-473, 2018 